УДК 336.6.371(477)

JEL: I 22

Лойко Валерія Вікторівна

доктор економічних наук, доцент, професор кафедри фінансів та економіки,

Київського університету імені Бориса Грінченка

м. Київ, Україна

ORCID ID: 0000-0003-3248-1585

e-mail:v.loiko@kubg.edu.ua

Поздєєва Катерина Вікторівна

аспірант кафедри фінансів та економіки

Київського університету імені Бориса Грінченка

м. Київ, Україна

ORCID ID: 0000-0003-3011-903X

e-mail: k.pozdieieva.asp@kubg.edu.ua

Жильцов Максим Олександрович

аспірант кафедри фінансів та економіки

Київського університету імені Бориса Грінченка

м. Київ, Україна

ORCID ID: 0000-0001-6960-1144

e-mail:m.zhyltsov@kubg.edu.ua

\title{
НОВІ ОРГАНІЗАЦІЙНО - ПРАВОВІ ФОРМИ ФУНКЦІОНУВАННЯ ЗАКЛАДІВ ОСВІТИ ЯК ОСНОВА УДОСКОНАЛЕННЯ ЕКОНОМІЧНОГО МЕХАНІЗМУ РОЗВИТКУ СИСТЕМИ ЗАГАЛЬНОЇ СЕРЕДНЬОЇ ОСВІТИ
}

Анотація. У статті досліджено розвиток нових організаційно-правових форм функціонування закладів загальної середньої освіти як основи удосконалення економічного механізму розвитку системи загальної середньої освіти. Виявлено, що за ознаками автономії та правочинності фінансово-економічної діяльності усі школи у даний час можна розподілити на школи комунальної та приватної форм власності. Визначено види закладів загальної середньої освіти, які фінансуються 3 державного бюджету: спеціальні школи-інтернати для обдарованих дітей, школи соціальної реабілітації, в яких утримуються неповнолітні правопорушники віком 11-14 років; 3 обласних бюджетів фінансуються: спеціальні школи, школиінтернати для дітей з вадами розвитку; загальноосвітні школи-інтернати; дитячі будинки; підвищення кваліфікації педагогічних кадрів; 3 районних бюджетів фінансуються: загальноосвітні школи, спеціалізовані школи, ліцеї, гімназії тощо, загальноосвітні школи-інтернати, дитячі будинки. Наведено переваги та недоліки функціонування закладів загальної середньої освіти у різних організаційноправових формах. Доведено ефективність застосування організаційно-правової форми функціонування закладу загальної середньої освіти у рамках здійснення державно-приватного партнерства. Виділено способи фінансування, які обгрунтовані у «Концепції нової української школи» щодо децентралізації фінансового забезпечення закладів загальної середньої освіти. Визнано, що в ідеалі потрібна система цільового фінансування кожної конкретної дитини, коли ресурси, що виділяються, будуть необхідні і достатні для того, щоб повністю реалізувати потенціал кожного учня.

Ключові слова: заклади загальної середньої освіти; організаційно-правові форми; керівник; органи виконавчої влади; фінансування; система; розвиток; економічний механізм; удосконалення.

DOI: http://doi.org/10.32750/2019-0208

\section{ВСТУП}

Постановка проблеми. Пропозиції щодо удосконалення фінансово-економічного механізму розвитку закладів загальної середньої освіти, отримання і використання ними фінансових ресурсів, можуть бути ефективно реалізовані тільки при забезпечення 
нових, більш прогресивних організаційно - правових умов діяльності цих закладів. Це в першу чергу стосується підвищення рівня самостійності та відповідальності шкіл за процес та результати управління фінансовими ресурсами. Тому важливе значення для системного вирішення питання удосконалення роботи економічного механізму $\epsilon$ запровадження нових організаційних форм роботи закладів та якісних змін у ідентифікації статусу цих закладів.

Аналіз останніх досліджень і публікацій. Питанням економічного розвитку закладів освіти, зокрема проблемі пошуків та залучення додаткового фінансування закладів освіти в Україні приділили у вагу у своїх працях наступні вчені: І.В. Феофанова, В.В. Кичкіна [1], Т.Ю. Бойко [2], В.А. Чередник [3], Л.Я. Беновська [4], С.О. Коваленко, Ю.О. Коскіна [5], О.І. Климчук [6], С.О. Сисоєва, О. М. Топузов, Н. П. Дічек, М.Д. Култаєва, О.Л. Караман, Н.Б. Антонець, К.Ю. Ладоня [7] та інших науковців. Здобутки вказаних вчених мають теоретичне та практичне значення у вказаній сфері і стали основою для проведення подальших досліджень 3 питання дослідження нових організаційно-правових форм функціонування закладів загальної середньої освіти як основи удосконалення економічного механізму розвитку системи загальної середньої освіти в Україні. Сучасний процес реформування системи загальної середньої освіти та окреслення тематика потребують проведення подальшого комплексного дослідження і висвітлення результатів.

Мета статті полягає у виявленні та окресленні нових організаційно-правових форм функціонування закладів загальної середньої освіти та наукове обгрунтування напрямів удосконалення економічного механізму розвитку системи загальної середньої освіти.

\section{РЕЗУЛЬТАТИ ДОСЛІДЖЕННЯ}

Виклад основного матеріалу дослідження. За роки незалежності, використовуючи протиріччя нормативно-правової бази, долаючи хронічне недофінансування одних статей шкільних видатків та повну відсутність фінансування інших статей, школи самотужки «народили» певне розмаїття організаційних форм, структур i методів, які повинні були забезпечити їх виживання, поточну життєдіяльність та перспективний розвиток.

За ознаками автономії та правочинності фінансово-економічної діяльності усі школи у даний час можна розподілити на школи комунальної та приватної форм власності. Школи приватної форми власності, які зареєструвалися, з одного боку, як автономні юридичні особи - суб'єкти форми господарювання з прибутковим статусом, а з іншого, як суб'єкти освітньої діяльності, з самого початку своєї діяльності:

- самостійно відкривали власні рахунки у комерційних банках;

- самостійно відраховували державі визначені законодавством податки, відрахування, збори, платежі;

- самостійно звітували перед податковою адміністрацією, державними фондами, органами державної статистики;

- самостійно взаємодіяли з контролюючими та правоохоронними органами;

- самостійно визначали у власному штатному розписі штат бухгалтерів.

"Розплатою" за вищевказані самостійності приватних шкіл з боку держави стали повна відсутність з 1999 року бюджетного фінансування загальної середньої освіти учнів цих шкіл, відлучення шкіл від держзамовлення на підручники, введення плати за документи про освіту, розрахунки за тепло та енергоносії, оренду приміщень, землекористування за ринковими комерційними розцінками. 
Згідно Закону України «про освіту» в Україні існує три рівні державного управління освітою - державний, обласний, районний, то і фінансування середньої освіти також здійснюється 3 бюджетів, що формуються на цих трьох рівнях: державному, обласному та районному [8]. Причому переважна частина бюджету освіти формується на рівні району. Кошти районного і обласного бюджетів складають приблизно 94-99\% всього бюджету середньої освіти.

Розподіл між видатками бюджетів різних рівнів відбувається таким чином.

3 Державного бюджету фінансуються [8,9]:

1) спеціальні школи-інтернати для обдарованих дітей (їх всього 3);

2) школи соціальної реабілітації, в яких утримуються неповнолітні правопорушники віком 11-14 років;

3) випуск підручників.

3 обласних бюджетів, фінансуються:

1) спеціальні школи, школи-інтернати для дітей з вадами розвитку;

2) загальноосвітні школи-інтернати;

3) дитячі будинки;

4) підвищення кваліфікації педагогічних кадрів.

з районних бюджетів:

1) загальноосвітні школи;

2) спеціалізовані школи, ліцеї, гімназії тощо;

3) загальноосвітні школи-інтернати, дитячі будинки (якщо 70\% контингенту формується в межах району).

Стосовно шкіл, що знаходяться в комунальній власності, то вони фактично не мають прав у веденні економічної діяльності, що в першу чергу проявляється в неможливості управляти власними коштами. Незважаючи на визначений одними положеннями законодавства статус школи як юридичної особи публічного права, інші положення законодавства не надали школі статусу суб'єкта господарювання. Школа 3 точки зору Цивільного кодексу України фактично є структурним підрозділом іншої юридичної особи - районного управління освіти, яка, у свою чергу, має повноваження розширювати або звужувати у певних межах самостійність школи з питань фінансовогосподарської діяльності [10]. При цьому були намагання з боку різних регіонів посилити рівень самостійності у прийнятті розпорядчих рішень, зокрема по наступним напрямам:

- створення окремого підрозділу у штатному розписі школи, куди входить бухгалтер (бухгалтери) та касир; відповідно, власного бухгалтерського обліку, податкової, статистичної та іншої звітності;

- ведення окремого балансу;

- самостійна реєстрація школи у податковій адміністрації, місцевих відділеннях пенсійного фонду та фондів соціального страхування;

- безпосередня взаємодія 3 контролюючими, правоохоронними та судовими органами;

- надання директору прав, як розпоряднику фінансів, підписувати цивільноправові договори з іншими фізичними та юридичними особами на виконання робіт, послуг та забезпечення школи матеріальними цінностями, потрібними для забезпечення навчально-виховного процесу, а також платіжні доручення на перерахування відповідних коштів;

- самостійна (за мінімальним погодженням) організація платних послуг, оренди тимчасово вільних приміщень та обладнання. 
Як показав досвід запровадження всіх цих заходів, основною проблемою $\epsilon$ невиконання місцевими органами державної влади та самоврядування продекларованих узгоджених умов щодо самостійного укладання договорів, ведення справ, мінімальних нормативів бюджетного фінансування та належного господарського обслуговування. Таким чином бюджетна установа не може мати ніяких крім бюджетних джерел фінансування, а також рух іï коштів, зокрема витрат, проводиться через систему державного казначейства. Робота бюджетної установи супроводжується рядом чинників, які реально обмежують його самостійність, зокрема:

- розрахунок розміру фінансування закладу остаточно визначається вищестоящим керівництвом, а саме фінансування заклад отримує жорстко по кодам витрат бюджетної класифікації - нормовано по кожному напряму використання;

- заклад обмежений у самостійному розпорядженні коштами, що отримує iз бюджету, у зв'язку із чим він не має повноцінної зацікавленості в провадженні програм iз ефективного використання ресурсів, коштів, матеріально-технічних засобів;

- заклад не $\epsilon$ самостійним у визначенні кількості осіб, що в ньому обслуговуються (зокрема в наборі учнів), а також значній мірі у визначенні якісних параметрів цього обслуговування, що відповідно зменшує зацікавленість у вдосконаленні кваліфікації кадрів, залученню нових фахівців;

- заклад хоча і зацікавлений в отриманні додаткових доходів до спецфонду, одержаних зокрема від реалізації платних послуг, але є обмежений у впровадженні програм як отримання, так і використання цих коштів, їх самостійному розпорядженні;

- заклад не може в значній мірі зацікавити свій персонал до більш продуктивної праці та підвищенні кваліфікації, оскільки дуже обмежений у запровадженні систем матеріального заохочення.

Крім того бюджетна установа не має юридичних повноважень для господарської самостійності. Так, наприклад, матеріальні цінності, передані бюджетній установі на благодійних засадах, обліковуються бухгалтерією у так званій натуральній формі, але також змушені бути проведені через облік Держказначейства. Тому деякі заклади додатково утворюють окрему юридичну особу - благодійний фонд, який має свої окремі рахунки в комерційному банку, свою бухгалтерію, свій кошторис та систематично співпрацює зі школою на підставі угоди про благодійну діяльність та прийнятої благодійної програми.

На нашу думку, існування закладів середньої освіти в статусі бюджетної установи не дозволяє реалізувати програми щодо ефективного забезпечення та використання фінансовими ресурсами. Необхідно шукати інші, більш сучасні досконалі, які б дати можливість запровадити нові підходи та методики в фінансово - економічній сфері. Кращою організаційно - правовою формою $є$ комунальне некомерційне підприємство.

Комунальне некомерційне підприємство має статус суб'єкта господарювання, який несе повну відповідальність за свою фінансово - господарську діяльність. На відміну від бюджетної установи діяльність комунального некомерційного підприємства базується на принципах госпрозрахунку та економічного заохочення.

Можна визначити основні засади щодо існування та діяльності такого підприємства:

- діяльність має здійснюватися згідно статуту суб’єкта господарювання;

- здійснення своєї діяльності без мети отримання прибутку;

- самостійне розпорядження виділеним комунальним майном, право проведення тендерів та укладання договорів на закупівлі;

- отримання фінансування без деталізації по напрямам використання (кодам), єдиною сумою; 
- наявність права відкриття філій, представництв, підрозділів;

- право керівництва визначати штатний розпис, значні повноваження у проведенні заходів із матеріального заохочення та стимулювання;

- обов'язок укладання трудових договорів (контрактів, угод) із працівниками та забезпечення соціальних гарантій;

- право більш повноцінного розпорядження коштами, отриманими не як бюджетне фінансування - платні послуги, благодійницькі внески, інші доходи не заборонені законодавством;

- самостійний розрахунок фінансового плану та його погодження у власника

Комунальні некомерційні підприємства на відміну від бюджетних установ мають ряд переваг при забезпеченні виконання важливих соціально-економічних функцій держави. До таких переваг можна віднести:

а) повноцінний статус юридичної особи.

Наступним кроком удосконалення системи управління фінансовими ресурсами закладів загальної середньої освіти після створення комунального підприємства може бути здійснення такого управління на основі нової сучасної форми, якою є державно приватне партнерство. Державно-приватне партнерство відповідно до Закону, прийнятому в 2010 р., це співробітництво між територіальною громадою в особі відповідних органів місцевого самоврядування (державними партнерами) та юридичними особами (крім державних та комунальних підприємств) або фізичними особами - підприємцями (приватними партнерами), що здійснюється на основі договору [11]. У місті Києві на стороні держави може виступати Київська міська державна адміністрація, яка може делегувати ці функції Департаменту освіти міста Києва.

На стороні приватного партнера у договорі, що укладається в рамках державноприватного партнерства, в можуть виступати приватні заклади освіти, що мають досвід в навчально - виховній діяльності, фізичні особи - педагоги, що також можуть використати свій багаторічний досвід. Крім того, в якості приватного партнера можуть виступати декілька осіб (об'єднання, пул партнерів), які несуть солідарну відповідальність за зобов'язаннями, передбаченими договором, що укладається в рамках державно-приватного партнерства. Визначення приватного партнера здійснюється виключно на конкурсних засадах.

Приватний партнер щоб отримати право на управління закладом повинен довести, що він забезпечить більш високі техніко-економічні та соціальні показники $\mathrm{i}$, відповідно, більш високий рівень ефективності діяльності, ніж у разі здійснення такої діяльності традиційним чином як бюджетна комунальна установа. Участь приватного партнера передбачає довготривалість відносин (від 5 до 50 років згідно Закону), що гарантує надійність та стабільність роботи закладу в новій системі управління. Крім того, такий шлях обов'язково передбачає внесення приватним партнером інвестицій в об'єкти партнерства із джерел, не заборонених законодавством. Тим самим гарантується більш високий рівень фінансування школи.

Найбільш ефективної формою у рамках здійснення державно-приватного партнерства, на нашу думку, є укладання договори про спільну діяльність із міським департаментом освіти, де мають бути чітко виписані функції, права та обов'язки кожної сторони. При цьому передача об'єктів, що перебувають у комунальній власності приватному партнеру для виконання умов договору, укладеного в рамках державноприватного партнерства, не зумовлює перехід права власності на ці об'єкти до приватного партнера. Такі об'єкти, в даному дослідженні школи підлягають 
поверненню комунальному органу влади після припинення дії договору, укладеного в рамках державно-приватного партнерства.

Фінансування державно-приватного партнерства може здійснюватися за рахунок:

- фінансових ресурсів приватного партнера;

- фінансових ресурсів, запозичених в установленому порядку;

- коштів державного та місцевих бюджетів;

- кошти від платних послуг, які надає заклад (наприклад, оренда приміщень)

- цільових регулярних благодійних внесків, а також разових благодійних внесків

- інших джерел, не заборонених законодавством.

«Концепцією нової української школи» перебачено автономію школи, справедливе фінансування і рівний доступ до ресурсів $[12,13]$. В умовах проведення реформи децентралізації фінансове забезпечення закладів загальної середньої освіти покладається на державні органи влади та територіальні громади. За Концепцією нової української школи у державі повинні бути створені умови для розширення державногромадського партнерства у сфері освіти через нові підходи до співфінансування та управління навчальними закладами.

В ідеалі потрібна система цільового фінансування кожної конкретної дитини, коли ресурси, що виділяються, будуть необхідні і достатні для того, щоб повністю реалізувати потенціал кожного учня. Тобто фінансові потоки мають чітко реагувати на індивідуальні здібності учнів. Якщо у дитини є нахили у будь - якому напрямі від математики до спортивних досягнень, фінансова система повинна забезпечувати індивідуальну підтримку кожного «таланту» у кожного школяра, забезпечуючи при цьому достатні кошти для фінансування освітнього стандарту кожного учня, незалежно від індивідуальних його талантів.

\section{ВИСНОВКИ ТА ПЕРСПЕКТИВИ ПОДАЛЬШИХ ДОСЛІДЖЕНЬ.}

На теперішній час повноцінно не можна індивідуалізувати фінансування освіти. Для цього, по - перше, недостатньо «прозорих» ресурсів, а, по - друге, школи не мають повноважень вільно розпоряджатись коштами, які їм виділяються. Тому необхідно 3 одного боку посилити фінансовий ресурсний потенціал через удосконалення механізмів залучення додаткових коштів, а $з$ другого надати школі більші права та можливості у використанні цих коштів.

\section{СПИСОК ВИКОРИСТАНИХ ДЖЕРЕЛ}

1.Феофанова I.В., Кичкіна В.В. Бюджетування як засіб контролю за використанням фінансових ресурсів закладів освіти. Бізнес-навігатор. 2018. № 6 (49). С. 48-53.

2.Бойко Т.Ю. Фінансування закладів освіти на міському рівні в умовах децентралізації влади в Україні. Науковий вісник Херсонського державного університету. 2017. Вип. 27. Частина 2. С. 147-151.

3.Чередник В.А. Джерела додаткового фінансування загальної середньої освіти в Україні. Науковий вісник Херсонського державного університету. 2015. Вип. 11.Частина 5. С. 116-119.

4.Беновська Л.Я. Проблеми бюджетного забезпечення освіти в контексті децентралізації управління. Регіональна економіка. 2016. № 1. С. 121-129.

5.Коваленко С.О., Коскіна Ю.О. Фінансування видатків на освіту в умовах децентралізації. Бізнесінформ. 2017. № 8. С. 105-109.

6.Климчук I.О. Фінансові аспекти економічної складової прогнозування та розвитку закладів освіти в Україні. Journal «Science Rise: Pedagogical Education». 2019. № 6 (33). C. 11-15.

7.Сисоєва С.О., Топузов О. М., Дічек Н. П., Култаєва М.Д., Караман О.Л., Антонець Н. Б., Ладоня К.Ю. Практична філософія і Нова українська школа. Інститут педагогіки НАПН України, м. Київ, Україна, 168 с.

8.Про освіту. Закон України № 2145 - VIII у редакції від 18.12.2019. URL: http://search.ligazakon.ua/l_doc2.nsf/link1/T172145.htm 
9.Про Національну стратегію розвитку освіти в Україні до 2021 року. Указ Президента України № 344/2013. URL: https://zakon3.rada.gov.ua/laws/show/344/2013

10.Цивільний кодекс України. URL: http://zakon3.rada.gov.ua/laws/show/435-15/print

11.Про державно-приватне партнерство. Закон України № 2404-VI у поточній редакції 20.10.2019. URL: https://zakon.rada.gov.ua/laws/show/2404-17\#Text

12.Концепція нової української школи: Концептуальні засади реформування української школи. 2016. URL: https://www.kmu.gov.ua/storage/app/media/reforms/ukrainska-shkola-compressed.pdf

13.Про затвердження Інструкції про організацію та діяльність гімназії. Інструкції про організацію та діяльність ліцею: Наказ Міністерства освіти України № 1/9-472. 28.10.2002. URL: https://zakon.rada.gov.ua/rada/show/v-472290-02 


\section{Лойко Валерия Викторовна}

доктор экономических наук, доцент,

профессор кафедры финансов и экономики,

Киевского университета имени Бориса Гринченка

г. Киев, Украина

ORCID ID: 0000-0003-3248-1585

e-mail:v.loiko@kubg.edu.ua

\section{Поздеева Екатерина Викторовна}

аспирант кафедры финансов и экономики

Киевского университета имени Бориса Гринченка

г. Киев, Украина

e-mail:pozdeeva.kv@ukr.net

ORCID ID: 0000-0003-3011-903X

Жильцов Максим Александрович

аспирант кафедры финансов и экономики

Киевского университета имени Бориса Гринченка

г. Киев, Украина

ORCID ID: 0000-0001-6960-1144

e-mail:m.zhyltsov@kubg.edu.ua

\section{НОВЫЕ ОРГАНИЗАЦИОННО - ПРАВОВЫЕ ФОРМЫ ФУНКЦИОНИРОВАННИЯ УЧРЕЖДЕНИЙ ОБРАЗОВАНИЯ КАК ОСНОВА СОВЕРШЕНСТВОВАНИЯ ЭКОНОМИЧЕСКОГО МЕХАНІЗМА РОЗВИТИЯ СИСТЕМЫ ОБЩЕГО СЕРЕДНЕГО ОБРАЗОВАНИЯ}

Аннотация. В статье исследовано развитие новых организационно-правовых форм функционирования учреждений общего среднего образования как основы совершенствования экономического механизма развития системы общего среднего образования. Выявлено, что по признакам автономии и правомочности финансово-экономической деятельности все школы в настоящее время можно разделить на школы коммунальной и частной форм собственности. Определены виды учреждений общего среднего образования, финансируемых из государственного бюджета: специальные школы-интернаты для одаренных детей, школы социальной реабилитации, в которых содержатся несовершеннолетние правонарушители в возрасте 11-14 лет; из областных бюджетов финансируются: специальные школы, школы-интернаты для детей с недостатками развития; общеобразовательные школы-интернаты; детские дома; повышение квалификации педагогических кадров; из районных бюджетов финансируются общеобразовательные школы, специализированные школы, лицеи, гимназии и т.П., общеобразовательные школы-интернаты, детские дома. Приведены преимущества и недостатки функционирования учреждений общего среднего образования в разных организационно-правовых формах. Доказана эффективность применения организационно-правовой формы функционирования учреждения общего среднего образования в рамках осуществления государственно-частного партнерства.Выделены способы финансирования, которые обоснованы в «Концепции новой украинской школы» по децентрализации финансового обеспечения учреждений общего среднего образования. В идеале нужна система целевого финансирования каждого конкретного ребенка, когда ресурсы, выделяемые будут необходимы и достаточны для того, чтобы полностью реализовать потенциал каждого ученика.

Ключевые слова: учреждения общего среднего образования; организационно-правовые формы; руководитель; органы исполнительной власти; финансирование; система; развитие; экономический механизм; совершенствование. 


\author{
Valeriia Loiko \\ D.Sc (Economics), Associate Professor, \\ Boris Grinchenko Kyiv University, \\ Kyiv, Ukraine \\ ORCID ID: 0000-0003-3248-1585 \\ e-mail:v.loiko@kubg.edu.ua
}

\title{
Kateryna Pozdieieva
}

Postgraduate Student, Department of Finance and Economics,

Boris Grinchenko Kyiv University,

Kyiv, Ukraine

ORCID ID: 0000-0003-3011-903X

e-mail: pozdeeva.kv@ukr.net

\section{Maxim Zhiltsov}

Postgraduate Student, Department of Finance and Economics, Boris Grinchenko Kyiv University,

Kyiv, Ukraine

ORCID ID: 0000-0001-6960-1144

e-mail:m.zhyltsov@kubg.edu.ua

\section{NEW ORGANIZATIONAL AND LEGAL FORMS OF FUNCTIONING EDUCATIONAL INSTITUTIONS AS A BASIS FOR IMPROVING THE ECONOMIC MECHANISM OF GENERAL SYSTEM DEVELOPMENT}

Abstract. The article examines the development of new organizational and legal forms of functioning general secondary education institutions as a basis for improving the economic mechanism of development of the general secondary education system. It was found that on the grounds of autonomy and legality of financial and economic activities, all schools can now be divided into schools of communal and private ownership. The types of general secondary education institutions financed from the state budget have been identified: special boarding schools for gifted children, social rehabilitation schools where juvenile offenders aged 11-14 are kept; from regional budgets are financed: special schools, boarding schools for children with disabilities; boarding schools; orphanages; advanced training of pedagogical staff; from the district budgets are financed: secondary schools, specialized schools, lyceums, gymnasiums, etc., boarding schools, orphanages. The advantages and disadvantages of the functioning of general secondary education institutions in various organizational and legal forms are given. The effectiveness of the application of the organizational and legal form of functioning of the institution of general secondary education in the framework of public-private partnership is proved. The methods of financing are substantiated, which are substantiated in the "Concept of the new Ukrainian school" regarding the decentralization of financial support of general secondary education institutions. It is recognized that, ideally, a system of targeted funding for each individual child is needed, when the resources allocated will be necessary and sufficient to fully realize the potential of each student.

Key words: general secondary education institutions; organizational and legal forms; head; executive bodies; financing; system; development; economic mechanism; improvement.

\section{REFERENCES (TRANSLATED AND TRANSLITERATED)}

1. Feofanova, I.V. \& Kichkina, V.V. (2018). Budgeting as a means of controlling the use of financial resources of educational institutions. Biznes-navihator [Accessed 18 December 2019] (in Ukrainian).

2. Boyko, T.Yu. (2017). Financing of educational institutions at the city level in the conditions of decentralization of power in Ukraine. Naukovyj visnyk Khersons'koho derzhavnoho universytetu, 27, part 2, P. 147-151. [Accessed 18 December]. (in Ukrainian).

3. Cherednik, V.A. (2015). Sources of additional funding for general secondary education in Ukraine. Naukovyj visnyk Khersons'koho derzhavnoho universytetu, 11, part 5, [Accessed 18 December]. (in Ukrainian).

4. Benovska, L.Ya.(2016). Problems of budget support of education in the context of decentralization of management. Rehional'na ekonomika, 1. P. 121-129. [Accessed 18 December]. (in Ukrainian).

5. Kovalenko, S.O. \& Koskina, Y.O. Financing of education expenditures in the conditions of decentralization. Biznes-inform, 8, P. 105-109. [Accessed 18 December]. (in Ukrainian). 
6. Klimchuk, I.O. (2019). Financial aspects of the economic component of forecasting and development of educational institutions in Ukraine. Journal «Science Rise: Pedagogical Education», 6 (33). P. 11-15. [Accessed 18 December]. (in Ukrainian).

7. Sysoeva, S.O., Topuzov, O.M., Dichek, N.P., Kultayeva, M.D., Karaman, O.L., Antonets, N.B. \& Ladonya K.Yu. Practical philosophy and the New Ukrainian school. Instytut pedahohiky NAPN Ukrainy, Kyiv, Ukraina, 168. [Accessed 18 December]. (in Ukrainian).

8. Law of Ukraine. About education № 2145-VIII. (2017, September 05). Retrieved November 12, 2018, from http://search.ligazakon.ua/l_doc2.nsf/link1/T172145.htm. [Accessed 1 December]. (in Ukrainian).

9. Decree of the President of Ukraine № 344/2013. On the National Strategy for the Development of Education in Ukraine until 2021. (2013, June 25). Retrieved November 15, 2018, from https://zakon3.rada.gov.ua/laws/show/344/2013. [Accessed 10 December]. (in Ukrainian).

10. Civil Code of Ukraine. URL: http://zakon3.rada.gov.ua/laws/show/435-15/print [Accessed 18 December]. (in Ukrainian).

11. Law of Ukraine. About public-private partnership (2019). URL: https://zakon.rada.gov.ua/laws/show/2404-17\#Text [Accessed 8 December]. (in Ukrainian).

12. The concept of a new Ukrainian school: Conceptual principles of reforming the Ukrainian school. 2016. URL: https://www.kmu.gov.ua/storage/app/media/reforms/ukrainska-shkola-compressed.pdf [Accessed 18 December]. (in Ukrainian).

13. On approval of the Instruction on the organization and activity of the gymnasium. Instructions on the organization and activities of the lyceum: Order of the Ministry of Education of Ukraine № 1 / 9-472. 10/28/2002 URL: https://zakon.rada.gov.ua/rada/show/v-472290-02. [Accessed 18 December]. (in Ukrainian). 